\title{
Role of growth factors in the pathogenesis of tissue fibrosis in systemic sclerosis.
}

\author{
Sergio A. Jimenez \\ Thomas Jefferson University \\ Susan V. Castro \\ Thomas Jefferson University \\ Sonsoles Piera-Velazquez \\ Thomas Jefferson University
}

Follow this and additional works at: https://jdc.jefferson.edu/medfp

Part of the Rheumatology Commons

Let us know how access to this document benefits you

\section{Recommended Citation \\ Jimenez, Sergio A.; Castro, Susan V.; and Piera-Velazquez, Sonsoles, "Role of growth factors in the pathogenesis of tissue fibrosis in systemic sclerosis." (2010). Department of Medicine} Faculty Papers. Paper 201.

https://jdc.jefferson.edu/medfp/201

This Article is brought to you for free and open access by the Jefferson Digital Commons. The Jefferson Digital Commons is a service of Thomas Jefferson University's Center for Teaching and Learning (CTL). The Commons is a showcase for Jefferson books and journals, peer-reviewed scholarly publications, unique historical collections from the University archives, and teaching tools. The Jefferson Digital Commons allows researchers and interested readers anywhere in the world to learn about and keep up to date with Jefferson scholarship. This article has been accepted for inclusion in Department of Medicine Faculty Papers by an authorized administrator of the Jefferson Digital Commons. For more information, please contact: JeffersonDigitalCommons@jefferson.edu. 


\section{Role of Growth Factors in the Pathogenesis of Tissue Fibrosis in Systemic Sclerosis}

*Sergio A. Jimenez, MD; Susan V. Castro, PhD; and Sonsoles Piera-Velazquez, PhD

Jefferson Institute of Molecular Medicine and Scleroderma Center, Thomas Jefferson University

Keywords: systemic sclerosis, fibrosis, growth factor, c-Abl, protein kinase c delta, imatinib mesylate.

\section{Corresponding Author}

Sergio A. Jimenez, M.D.

Professor and Co-Director

Jefferson Institute of Molecular Medicine and

Professor of Biochemistry and Molecular Biology

Thomas Jefferson University

233 S. $10^{\text {th }}$ Street, Suite 509 BLSB

Philadelphia, PA 19107. USA.

T: 215-503-5042 / F: 215-923-4649

Sergio.Jimenez@jefferson.edu 


\begin{abstract}
(132 words; 200 max)
The most severe clinical and pathologic manifestations of systemic sclerosis (SSc) are the result of a fibrotic process characterized by the excessive and often progressive deposition of collagen and other connective tissue macromolecules in skin and numerous internal organs. The mechanisms involved in the initiation and progression of the remarkable fibrotic process in SSc remain largely unknown. Extensive recent studies have indicated that a variety of polypeptide growth factors play a crucial role in this process. The most commonly implicated growth factors include transforming growth factor beta (TGF- $\beta$ ), connective tissue growth factor (CTGF), platelet derived growth factor (PDGF), and vascular endothelial growth factor (VEGF). Here, the experimental evidence supporting the participation of various growth factors in the pathogenesis of the fibrotic process in SSc and the molecular mechanisms involved will be reviewed.
\end{abstract}




\section{(6,661 words)}

The pathogenesis of Systemic Sclerosis (SSc) is complex and despite numerous studies that have examined several aspects of its intricate picture, the exact mechanisms involved are not well understood [1-4]. However, it is apparent that the most severe clinical and pathologic manifestations of the disease are the result of a fibrotic process characterized by the excessive and often progressive deposition of collagen and other connective tissue macromolecules in skin and numerous internal organs. Tissue fibrosis in SSc is the result of an upregulated expression of genes encoding collagen and other extracellular matrix proteins in affected organs. This is the most important difference that distinguishes normal fibroblasts that promote normal wound healing from SSc fibroblasts which display exaggerated and uncontrolled collagen and extracellular matrix (ECM) production resulting in pathologic organ fibrosis [5-8].

The excessive collagen deposition in SSc is due to overproduction of this protein by an expanded population of activated fibroblasts. Fibroblasts cultured in vitro from affected SSc skin show characteristic features distinct from those of normal fibroblasts. SSc fibroblasts appear to be very active in protein synthesis as demonstrated by the presence of distended and enlarged rough endoplasmic reticulum, abundant cytoplasm, and numerous membrane-bound vesicles containing proteinaceous amorphous material that most likely represent the exportation of newly synthesized collagen and other ECM macromolecules into the extracellular space. The exaggerated production of collagen and ECM proteins by SSc fibroblasts is maintained for serial passages in vitro, suggesting that fundamental alterations in the regulation of collagen gene expression have occurred in these cells $[9,10]$.

A hallmark of the activation of fibroblasts is their conversion into myofibroblasts, a process in which cells acquire the expression of smooth muscle actin and develop contractile and 
migratory properties [11]. In addition to their motile and contractile phenotype, myofibroblasts display highly increased biosynthetic activity for collagen and other ECM proteins. The transition into myofibroblasts involves a unique process of phenotypic transdifferentiation by which quiescent fibroblasts, epithelial cells or endothelial cells/pericytes acquire myofibroblast characteristics [12-14].

The origin of the overproducer fibroblasts in SSc has not been completely elucidated and it is likely that several different pathways lead to the tissue expansion and accumulation of these cells [15]. At least three distinct mechanisms of fibroblast expansion occurring in fibrotic diseases have been identified. These include: (1) the activation of resident fibroblasts and the selection of matrix overproducer and apoptosis resistant cells [16,17] through the effects of cytokines and growth factors released from inflammatory cells infiltrating the affected tissue, (2) the recruitment of circulating fibrocytes, a unique population of bone marrow derived mesenchymal cell precursors characterized by the presence of both mesenchymal cell and bone marrow origin markers [18-20] and (3) the transdifferentiation into myofibroblasts of either epithelial cells or vascular cells such as pericytes or endothelial cells, in epithelial to mesenchymal (EMT) or endothelial to mesenchymal transitions (EndoMT), respectively [12-14, 21-24].

\section{Growth Factors}

The mechanisms involved in the initiation and progression of the remarkable fibrotic process in SSc remain largely unknown [1-4]. However, extensive recent studies have indicated that a variety of polypeptide growth factors play a crucial role in this process. In the following sections the experimental evidence supporting the participation of various growth factors in the 
pathogenesis of the fibrotic process in SSc and the molecular mechanisms involved will be reviewed.

Transforming growth factor beta (TGF- $\beta$ ). TGF- $\beta$ is a pleotropic growth factor that plays crucial roles during embryogenesis, development of the immune system, malignant cell transformation, vascular morphogenesis, inflammatory response, and wound healing, among many others [25-27]. There are three isoforms of TGF- $\beta$ which in addition to their primary structure differ in their cellular origin, the kinetics of their expression, and their overall effects, which are often organ specific and context-dependent. TGF- $\beta 1$ is the most abundant isoform and is most frequently implicated in the pathogenesis of various fibrotic processes including those associated with SSc. TGF- $\beta 1$ is produced by a large variety of cells, including fibroblasts and macrophages, and most cells in the body have receptors for this isoform. TGF- $\beta$ is initially produced in a latent form in which the polypeptide is bound to a latency-associated peptide (LAP) and is carried to the extracellular compartment as a large complex with a carrier protein, latent TGF- $\beta$ binding protein (LTBP). LTBP shuttles latent TGF- $\beta$ to a storage compartment comprised of ECM proteins such as elastin fibrils and fibronectin-rich pericellular matrices [2829]. Release of active TGF- $\beta$ from the ECM storage sites requires either proteolytic cleavage, which can be accomplished by numerous proteases including plasmin and certain matrix metalloproteinases, or by conformational changes induced by interactions with thrombospondin or certain integrins such as $\alpha v \beta 6[30,31]$.

Canonical pathway of TGF- $\beta$ signaling. Once activated, bioactive TGF- $\beta$ in a dimeric form binds to one of several transmembrane kinase receptors $(\mathrm{T} \beta \mathrm{R})$ and initiates a complex series of intracellular reactions that transduce the signal from the cell surface to the nucleus and eventually to the transcriptional regulatory elements of numerous TGF- $\beta$-responsive genes. The 
signaling events involve numerous intracellular molecules and pathways as illustrated in Fig. (1). The classic pathway of TGF- $\beta$ signal transduction involves the Smad family of intracellular proteins [32-36] and is initiated by binding of dimeric TGF- $\beta$ to the constitutively active serine/threonine $\mathrm{T} \beta \mathrm{RII}$ which recruits $\mathrm{T} \beta \mathrm{RI}$ and then transphosphorylates it on three to five serine and threonine residues in a short (30 amino acid) regulatory sequence known as the GS region. T $\beta R$ I is a member of a family of at least seven proteins known as activin receptor like kinases (ALK). In fibroblastic cells the T $\beta R I$ is ALK-5 whereas in endothelial cells it is ALK-1 although signaling through ALK-1 has also been observed in fibroblasts (see Fig (1)). The phosphorylated T $\beta R I$ receptor transduces the signal to the nucleus through the Smad family of proteins. Smad2 or Smad3, two of the five receptor activated Smads (RSmads) then associate with another protein, SARA, and become phosphorylated by the activated T $\beta$ RI. Phosphorylation allows these proteins to form a complex with the co-Smad, Smad4, which is a cytoplasmic shuttle protein involved in the translocation of the Smad complex across the nuclear membrane into the nucleus. Once in the nucleus, Smad3/Smad4 complexes act as transcription factors by binding to specific DNA binding sites in the promoter regions of target genes and thereby activating their expression [37]. In contrast, Smad2/Smad4 complexes do not appear to directly bind to DNA promoter sites but instead exert their effect through their interactions with other transcription factors or co-activator proteins. In addition to the ALK-5 initiated signaling, it has been shown that in dermal fibroblasts important fibrogenic gene programs can also be induced by ALK-1-mediated activation of Smad1 [38].

Fine tuning of TGF- $\beta$ activity is achieved through a balance of positive and negative effector molecules [39]. Of critical importance is the inhibitory Smad, Smad7, which inhibits TGF- $\beta$ signaling by binding to the type I receptor and thereby preventing recruitment and 
phosphorylation of RSmads [40,41]. Smad7 also facilitates T $\beta$ RI ubiquitination by the Smurf proteins by targeting the receptor for degradation, which leads to inhibition of RSmad activation [42]. Other mechanisms of fine regulation include dephosphorylation of Smads through specific phosphatases as well as regulation of Smad nucleocytoplasmic shuttling and nuclear trapping.

Non-canonical pathways of TGF- $\beta$ signaling. Numerous studies have shown that important TGF- $\beta$ functions are mediated by protein cascades that are independent of Smad2/Smad3 signaling and that these pathways may become activated in a cell-specific and context-dependent manner [43-45]. These non-Smad pathways involve a variety of other proteins such as, for example, the non-receptor tyrosine kinase cytoplasmic Abelson kinase (c-Abl), protein kinase $\mathrm{C}-\delta(\mathrm{PKC}-\delta)$, phosphoinositol 3 kinase (PI3K), and Akt/PKB as shown in Fig. (1). Numerous recent studies have demonstrated the involvement of non-Smad pathways in the development of tissue fibrosis in SSc and have suggested that pharmacologic interventions directed at the blockade of one or more components of these pathways may prove to be effective therapeutic approaches for the disease.

Cytoplasmic Abelson kinase (c-Abl). c-Abl is a non-receptor tyrosine kinase implicated in numerous intracellular transduction pathways including cell differentiation, cell division, cell adhesion, and stress responses. Translocation of the genomic region containing the gene encoding c-Abl from chromosome 9 to chromosome 22 is responsible for the development of chronic myelogenous leukemia [46,47]. A recent review discussed numerous recent studies showing that activation of $\mathrm{c}-\mathrm{Abl}$ induced by TGF- $\beta$ is likely to contribute to the fibrosis and vasculopathy of the skin and internal organs in SSc [48]. One additional mechanism involving the c-Abl kinase has been implicated in the development of fibrosis in SSc. This study focused on the activation of Smad1 in SSc and found that that levels of phosphorylated Smad1 were 
found to be significantly elevated in SSc skin biopsy samples and in cultured SSc fibroblasts. The potent tyrosine kinase inhibitor, imatinib mesylate, blocked activation of the Smad1 pathway in TGF- $\beta$ stimulated control fibroblasts and reversed activation of this pathway in SSc fibroblasts. These findings demonstrated that activation of Smad1 signaling contributes to the persistent activation of SSc fibroblasts and that this pathway is blocked by imatinib mesylate [49]. The role of c-Abl as an important mediator of tissue fibrosis in SSc has been further supported by numerous studies in vitro in cultured fibroblasts as well as in animal models of SSc and fibrosis, and by numerous reports of uncontrolled clinical studies describing SSc patients who experienced improvement in cutaneous sclerosis in response to imatinib mesylate therapy $[50-53]$.

PI3K/Akt Pathways. Critically important pathways are initiated by TGF- $\beta$ activation of phosphoinositide 3-kinases (PI3Ks), which phosphorylate inositol-containing lipids to yield phosphoinositol 3 phosphate $\left(\mathrm{PIP}_{3}\right)$ [54]. $\mathrm{PIP}_{3}$ then recruits the phosphoinositide-dependent kinase (PDK)-1 and Akt/protein kinase $\mathrm{B}(\mathrm{PKB})$, bringing these proteins into proximity at the plasma membrane where Akt/PKB is phosphorylated by PDK-1 [55]. Once activated, Akt leaves the plasma membrane to phosphorylate intracellular substrates and also translocates to the nucleus where it can phosphorylate and activate transcription factors. Studies in several cell systems, including human mesangial cells and lung and dermal fibroblasts, suggest that Akt may have dual profibrotic effects, increasing collagen synthesis and decreasing its degradation via downregulation of matrix metalloproteinase 1, and several studies have shown that specific Akt inhibition may have a potent antifibrotic effect [56]. Furthermore, Akt/PKB may participate in EMT induction through phosphorylation of GSK-3 and also increase cell proliferation and survival through its inhibition of apoptotic pathways. The potential role of PI3K and Akt/PKB in 
the pathogenesis of tissue fibrosis in SSc has been supported by studies which showed enhanced activation of Akt in SSc fibroblasts [57] and elevated activity of PI3K and Akt/PKB in platelets from patients with SSc [58].

Protein kinase $\mathbf{C}-\boldsymbol{\delta}(\mathbf{P K C}-\boldsymbol{\delta}) . \mathrm{PKC}-\delta$ is a serine- and threonine-specific protein kinase involved in cell signaling and in the regulation of growth, apoptosis, and differentiation of a variety of cell types. Several studies examined the role of PKC- $\delta$ in the pathogenesis of fibrotic diseases including SSc. Fibroblasts from patients with SSc were shown to contain higher PKC- $\delta$ levels than normal cells and further studies demonstrated that PKC- $\delta$ was capable of inducing a potent stimulation of collagen gene expression. $\mathrm{PKC}-\delta$ inhibition with the highly specific inhibitor, rottlerin, or by expression of a dominant-negative PKC- $\delta$ construct reduced type I collagen production and abrogated TGF- $\beta$ stimulation of collagen gene expression in human fibroblasts [59]. Other studies examined the role of PKC- $\delta$ on the repression of TGF- $\beta$ activity and focused on the transcription factor Fli1 (Friend leukemia integration-1) [60,61]. Fli1 binds directly to the $\alpha 2$ type I human collagen gene promoter, inhibiting its transcription. Fli1 reduction increased TGF- $\beta$-dependent profibrotic gene expression, whereas increased Fli1 expression blocked these effects. Study of the mechanisms responsible indicated that TGF- $\beta$ induces phosphorylation of PKC- $\delta$ which in turn phosphorylates Fli1. This step is essential for Fli1 release from the collagen gene promoter with the resulting removal of its inhibitory influence and a consequent increase in the $\alpha 2(\mathrm{I})$ collagen gene transcriptional activity. These observations confirmed earlier studies demonstrating that inhibition of PKC $-\delta$ by pharmacologic or molecular biologic techniques diminished the expression of types I and III collagens induced by TGF- $\beta$ as well as the increased expression of these genes by cultured SSc fibroblasts $[59,60]$. 
Caveolin-1 regulation of TGF- $\boldsymbol{\beta}$ signaling. Another recently identified mechanism of regulation and fine tuning of TGF- $\beta$ activity involves caveolin-1. Caveolin-1, the most important member of a family of proteins found in lipid rafts, plays an important role in TGF- $\beta$ signaling regulation owing to its participation in T $\beta R$ internalization as illustrated in Fig. (2). $\mathrm{T} \beta \mathrm{R}$ are internalized both by caveolin- 1 associated lipid rafts and by early endosome antigen 1 (EEA-1) non-lipid raft pathways. It has been shown, furthermore, that non-lipid raft associated internalization increases TGF- $\beta$ signaling, whereas, caveolin-associated internalization increases T $\beta \mathrm{R}$ degradation, thereby effectively decreasing or abolishing TGF- $\beta$ signaling [62]. Specifically, it was demonstrated that SARA and Smurf, upstream regulators of either TGF- $\beta$ signaling or T $\beta \mathrm{R}$ degradation, respectively, were localized in distinct subcellular compartments. The complex SARA/Smad2/3 which initiates T $\beta$ R-1 signaling was found to be localized in a non-lipid raft EEA-1 positive compartment, whereas the Smurf/Smad7 complex responsible for initiating proteasome degradation of T $\beta$ Rs was found to be localized in caveolin-1 positive lipid rafts. The localization of the T $\beta$ Rs in the EEA-1 positive compartment was responsible for downstream Smad activation, whereas their localization in caveolae lipid rafts caused recruitment of Smurf/Smad7 with subsequent receptor ubiquitination and rapid receptor degradation and turnover $[63,64]$.

This novel mechanism of regulation of $\mathrm{T} \beta \mathrm{R}$ function and activity follows ligand engagement and is dependent on the fluidity of the membrane and the membrane density of the distinct caveolin-1 and non-caveolin compartments. Thus, absence of one compartment or imbalance in the densities of the two compartments may affect the level of TGF- $\beta$ pathway activity given the same amount of ligand binding. Furthermore, since this process occurs at the level of internalization of the T $\beta R$ immediately following ligand engagement, it likely represents 
an important mechanism of regulation of TGF- $\beta$ signaling. Thus, a reduction of caveolin-1 would result in uncontrolled activation of all TGF- $\beta$ mediated pathways including those responsible for tissue fibrosis. One unique feature of this regulation mechanism is that it provides a cogent and plausible mechanism for the perpetuation of tissue fibrosis following an initial triggering event. The triggering event results in a decrease in caveolin-1 gene expression; this decrease then shifts TGF- $\beta$ internalization through the EEA-1 pathway, leading to accentuation of the TGF- $\beta$-induced fibrotic effects and simultaneously causing further downregulation of caveolin-1 gene expression. Thus, the current evidence indicates that caveolin-1 is a crucial regulator of TGF- $\beta$ intracellular signaling and T $\beta \mathrm{R}$ endosomal degradation and, therefore, may play a key role in the pathogenesis of disorders characterized by exaggerated tissue fibrosis.

Numerous studies have supported this role of caveolin-1 in the development of tissue fibrosis [65-68]. For example, it was shown that caveolin-1 knockdown in vitro markedly increased collagen gene expression in normal human lung fibroblasts and that caveolin-1 was reduced in affected SSc lungs and skin [66] and in lung tissues and fibroblasts from patients with idiopathic pulmonary fibrosis [67,68]. Increasing caveolin-1 expression markedly improved bleomycin-induced pulmonary fibrosis [67]. Furthermore, restoration of caveolin function employing cell permeable peptides abrogated TGF- $\beta$ activation of cultured human dermal fibroblasts, and it was suggested that restoration of caveolin function employing the active caveolin-1 scaffolding domain coupled to cell-permeable carrier peptides may represent a novel approach for treatment of fibrotic diseases including SSc $[65,66]$.

Roles of TGF- $\boldsymbol{\beta}$ in SSc-associated tissue fibrosis. Numerous studies have shown that alterations in TGF- $\beta$ signaling are involved in the pathogenesis of diverse human diseases [69- 
72]. However, owing to its multiple and potent profibrotic effects, TGF- $\beta$ has been considered one of the key molecules involved in the pathogenesis of a variety of fibrotic diseases as well as in SSc tissue fibrosis [1-4,73-77]. One of the most important effects of TGF- $\beta 1$ is the stimulation of the synthesis of a variety of ECM macromolecules by fibroblasts and other mesenchymal cells as evidenced by a remarkable increase in response to TGF- $\beta$ treatment of the production of collagens type I, III, V, and VI, fibronectin and $\alpha$-smooth muscle actin ( $\alpha$-SMA), a molecular marker of activated myofibroblasts [78-83]. TGF- $\beta 1$ also decreases the synthesis of collagen-degrading metalloproteinases and stimulates the production of protease inhibitors such as tissue inhibitor of metalloproteinases 1 (TIMP-1) [84,85]. Small amounts of TGF- $\beta$ sensitize fibroblasts to its own effects and maintain them in a persistently activated state involving an autocrine mechanism that causes further production of TGF- $\beta$ [86]. It has also been shown that SSc fibroblasts express increased numbers of TGF- $\beta$ receptors on their surface and display altered ratios of these receptors, alterations that have been suggested to account for the increased TGF- $\beta$-induced signaling and the resulting stimulation of collagen production in these cells [87]. Another important profibrotic effect of TGF- $\beta$ is the induction of epithelial-mesenchymal transition $[12-14,88,89]$ and although less extensively studied, it also appears that TGF- $\beta$ might induce a similar transdifferentiation process in endothelial cells [22-24]. Another important effect of TGF- $\beta$ is the potent downregulation of caveolin-1 expression resulting in a marked reduction of its protein levels. As discussed above and illustrated in Fig. (2), a reduction in caveolin-1 would allow the uncontrolled and persistent activation of TGF- $\beta$ mediated pathways.

A large number of studies have examined various aspects of the complex TGF- $\beta$ pathway to determine the role of this growth factor in SSc pathogenesis. The various steps of TGF- $\beta$ signaling including the extracellular processing and the intricate intracellular signaling pathways 
involved in the TGF- $\beta$ pleotropic effects have been extensively examined in SSc fibroblasts and tissues. The circulating levels of active TGF- $\beta 1$ were measured in a cross-sectional study of diffuse or limited SSc in comparison with healthy controls. No significant differences were found in the levels of total serum TGF- $\beta 1$. However, patients with diffuse SSc consistently displayed lower levels of active TGF- $\beta 1$ than patients with limited SSc or normal individuals. The reduction in TGF- $\beta 1$ correlated with recent onset and more extensive skin sclerosis, suggesting that active TGF- $\beta 1$ may be sequestered in actively involved SSc skin [90].

Several studies examined the spontaneous production of active and total (active plus latent) TGF- $\beta 1$ by cells from SSc patients. One study examined the production of TGF- $\beta$ from peripheral blood mononuclear cells (PBMC). Greater amounts of both latent and active TGF- $\beta$ were produced by PBMC from SSc patients than those from normal subjects in autologous mixed lymphocyte reaction assays [91]. Another study showed that PBMC from patients with limited or diffuse cutaneous SSc had significantly elevated values compared to PBMC from normal controls. Furthermore, PBMC from patients with disease of recent onset displayed increased production of active or total TGF- $\beta 1$ compared to patients with disease of less recent onset. However, although the production of active TGF- $\beta 1$ by PBMC from patients with diffuse SSc was higher compared with PBMC form patients with limited SSc, the differences were not statistically significant. Analysis of leukocyte subsets showed that the spontaneous production of total TGF- $\beta 1$ in SSc patients was significantly higher in cultured peripheral monocytes/macrophages, but not in T cells, B cells, or NK cells [92]. In subsequent studies, the production of active and total TGF- $\beta 1$ levels by cultured dermal fibroblasts was measured. SSc fibroblasts expressed increased levels of TGF- $\beta$ type I and type II receptors but the secreted amounts of TGF- $\beta$ were similar to those secreted by normal fibroblasts [93]. 
The initial step in activation of the TGF- $\beta$ signaling pathway involves the release of the active polypeptide from its sequestered precursor bound in a latent state to ECM proteins. One of the novel mechanisms involved in this process was recently shown to require the induction of conformational changes in the protein by $\alpha v \beta 5$ integrin [31]. Therefore it was of interest to examine the levels of this integrin in SSc. In one study, levels of $\alpha v \beta 5$ expression were found to be significantly elevated in SSc fibroblasts compared with normal fibroblasts, and treatment of these cells with anti- $\alpha v \beta 5$ antibody or $\beta 5$ antisense oligonucleotide significantly blocked the TGF- $\beta$ pathway causing reduced collagen gene promoter activity and reversal of the myofibroblastic features of SSc fibroblasts. These results indicated that upregulated expression of $\alpha v \beta 5$ integrin contributes to the establishment of autocrine TGF- $\beta$ signaling in SSc fibroblasts through activation of endogenous latent TGF- $\beta 1$ [94].

Following release of active TGF- $\beta$ from its ECM storage sites, a dimeric form of the polypeptide engages the corresponding cellular membrane receptor. Studies of the expression levels of TGF- $\beta$ receptors in SSc skin biopsies using in situ hybridization and immunohistochemical analysis showed that the expression levels of both T $\beta$ RI and T $\beta$ RII were elevated in the dermal fibroblasts of SSc skin sections in comparison to normal skin sections, and the numbers of fibroblasts expressing these $T \beta R$ were increased in the SSc skin sections compared to normal controls. These results suggested that an autocrine TGF- $\beta$ signaling due to the overexpression of T $\beta$ RI and T $\beta$ RII in dermal fibroblasts is involved in the pathogenesis of dermal fibrosis in patients with SSc [95].

In fibroblasts, TGF- $\beta$ signaling occurs primarily through the ALK-5 type I T $\beta$ R receptor which triggers the canonical Smad signaling pathway. Accordingly, numerous studies have examined these early steps of the TGF- $\beta$ signaling cascade. In one study, the effects of 
SB431542, a small-molecule inhibitor of ALK-5, were examined in cultured fibroblasts and it was shown that SB431542 abrogated TGF- $\beta$-induced phosphorylation and nuclear transport of endogenous Smad2/3 and Smad4 and it inhibited TGF- $\beta$-induced stimulation of collagen, fibronectin, and connective tissue growth factor gene expression. The ALK-5 inhibitor also abolished TGF- $\beta$ autoinduction and myofibroblast transdifferentiation [96]. In a related study, the effect of the ALK-5 inhibitor SD208 on the expression of key biochemical markers of the fibrotic phenotype was compared in SSc fibroblasts and in normal fibroblasts. Inhibition of ALK-5 reduced the expression of a cohort of fibrotic markers by SSc dermal fibroblasts, including type I collagen and $\beta 1$ integrin, and attenuated the elevated adhesive and contractile properties of SSc fibroblasts indicating that some of the key profibrotic features of SSc fibroblasts are dependent upon ALK-5 activity [97].

A large number of studies exploring the intracellular steps of TGF- $\beta$ signal transduction in SSc cells have been reported. In particular, the role of Smad proteins in the pathogenesis of tissue fibrosis in SSc has been studied extensively and it has become apparent that the complex pathway involving intracellular Smad proteins is of crucial importance in the regulation of the fibrotic response in SSc [36,98-100]. One study examined the expression levels of Smad2, Smad3 and Smad4, as well as Smad3 phosphorylation in parallel with an assessment of the transcriptional activity of collagen genes in SSc cultured fibroblasts. Increased Smad3 phosphorylation and increased collagen gene transcriptional activity were found in SSc fibroblasts compared with normal fibroblasts. The induced overexpression of Smad3 caused a potent increase in collagen gene promoter activity in normal fibroblasts. These results demonstrated an important role of the Smad3 activation of the canonical TGF- $\beta$ signaling pathway in the stimulation of collagen gene transcriptional activity in SSc fibroblasts [101]. 
To further characterize the mechanism of regulation of collagen gene expression in SSc and healthy skin fibroblasts the roles in TGF- $\beta$ signaling of the p38 mitogen-activated protein kinase (MAPK) which is an important regulator of stress responses and apoptosis, and of the coactivator histone acetyl transferase p300, which regulates cell differentiation, were examined. In the studies of $\mathrm{p} 38$, treatment of dermal fibroblasts with TGF- $\beta$ resulted in a prolonged activation of this kinase. Furthermore, a specific inhibitor of p38 suppressed TGF- $\beta$ stimulation of collagen type I mRNA and the $\alpha 2(\mathrm{I})$ collagen promoter activity, whereas ectopic expression of $\mathrm{p} 38 \alpha$ enhanced the promoter activity of the collagen gene and potentiated TGF- $\beta$ stimulation of this promoter. However, both cell types exhibited similar total levels of p38 MAPK and similar kinetics of $\mathrm{p} 38$ activation in response to TGF- $\beta$ suggesting that the p38 MAPK pathway is not dysregulated in SSc fibroblasts [102]. In the studies with p300 it was shown that TGF- $\beta$ induced an increase in p300 levels in normal fibroblasts and that forced expression of p300 dramatically enhanced the magnitude of TGF- $\beta$ responses. Furthermore, TGF- $\beta$ lost its ability to induce Smad-dependent transcription in p300-depleted fibroblasts. These responses could be fully rescued with ectopic p300. Levels of p300 were higher in cultured fibroblasts derived from SSc patients than in fibroblasts from matched normal controls. These results established conclusively that p300 is an essential component of the cellular TGF- $\beta$ signal transduction pathways mediating stimulation of collagen synthesis in fibroblasts and may, therefore, be an important contributor to the progression of skin fibrosis in SSc and may represent a novel therapeutic target [103].

TGF- $\beta$ microarray/Analysis of global gene expression and SSc pathogenesis. The recent development of high throughput genomic profiling technologies such as cDNA microarrays, combined with advanced computational approaches, allow the identification and 
characterization of high-resolution expression profiles of numerous disease states, the detailed analysis of molecular networks that underlie specific disease phenotypes and the discovery of novel targets for therapeutic intervention.

Global gene expression studies have advanced substantially current understanding of SSc pathogenesis and will very likely provide molecular signatures that may allow the identification of SSc patients who may respond and benefit from specific therapies. One such study employed genome-wide gene expression microarrays to identify the pattern of TGF- $\beta$-responsive genes in SSc fibroblasts. The TGF- $\beta$-responsive signature comprising 674 uniquely expressed genes was present in about $60 \%$ of diffuse SSc skin biopsies, but was not found in limited SSc, morphea, or healthy control biopsies. The clinical subset of the TGF- $\beta$-responsive signature patients showed more severe skin involvement and a higher likelihood of scleroderma lung disease and is more likely to derive clinical benefit form anti-TGF- $\beta$ therapeutic approaches [104].

Connective tissue growth factor (CTGF). CTGF, also known as CCN2, is another pleotropic growth factor that has recently emerged as an important mediator of normal and pathological tissue fibrotic responses [105-107] and has been suggested to play a crucial role in SSc tissue fibrosis [108-110]. CTGF was originally identified in human umbilical vein endothelial cells, and previous studies revealed that human skin fibroblasts produce CTGF following stimulation with TGF- $\beta$ [105]. In addition to a potent profibrotic effect, CTGF participates in angiogenesis, axial development of the musculoskeletal system, structural organization of connective tissues, and embryo implantation. TGF- $\beta$ stimulates CTGF synthesis in fibroblasts, vascular smooth muscle cells and endothelial cells, and numerous studies have shown that it represents a downstream mediator of TGF- $\beta$ fibrogenic effects. Indeed, the CTGF produced by these cells in response to TGF- $\beta$ stimulation in turn stimulates the synthesis of such 
ECM components as type I collagen and fibronectin in dermal and lung fibroblasts and very likely also in endothelial cells. These observations prompted a large number of studies examining the role of CTGF in the pathogenesis of SSc [108-110]. A study to determine the clinical correlation of CTGF serum levels in patients with SSc showed that SSc patients with elevated CTGF had disease of more recent onset and of greater severity, including the more frequent development of pulmonary fibrosis with decreased DLCO and decreased vital capacity. Thus, serum CTGF levels were increased in patients with more severe SSc and correlated with the extent of skin sclerosis and the severity of pulmonary fibrosis [111]. Another study assessed CTGF expression in SSc tissues and found strong CTGF signals in fibroblasts of affected skin from patients with SSc, whereas there was no expression in the skin from normal controls [112]. CTGF has also been found to be overexpressed in lung fibroblasts isolated from SSc patients. A recent study examined CTGF induced changes in the lung fibroblast proteome and identified novel CTGF-responsive molecules that may play important roles in pulmonary fibrosis. One of these novel CTGF-induced proteins, IQ motif containing GTPase activating protein (IQGAP) 1, was found to be elevated in lung fibroblasts isolated from SSc patients with pulmonary fibrosis. Depletion of IQGAP1 expression by small interfering RNA inhibited CTGF-induced cellular migration. These findings further implicate the importance of CTGF in lung tissue repair and fibrosis [113].

Platelet-derived growth factor (PDGF). Members of the PDGF family, which is comprised of four different polypeptides (PDGF-A, B, C, and D) that form disulfide-bonded dimers (PDGF-AA, BB, CC, DD, and $\mathrm{AB}$ ), play an important role during embryonic development and contribute to the maintenance of connective tissue in adults. PDGF are potent mitogens and chemoattractants for a variety of inflammatory and mesenchymal cells, in 
particular, for vascular smooth muscle cells [114]. PDGF effects are mediated by a complex cascade initiated by activation of two distinct receptor tyrosine kinases (PDGFR $\alpha$ and $\beta$ ) that drive a potent mitogenic stimulation of vascular smooth muscle cells and dermal fibroblasts [115]. Dysregulation of PDGF signaling has been linked to numerous disorders including atherosclerosis and pulmonary hypertension [116,117]. PDGF has also been implicated in the pathogenesis of numerous fibroproliferative diseases, including SSc [118-119]. Elevated expression of PDGF and its receptors has been found in SSc skin and lung tissues and there is evidence that TGF- $\beta$ stimulates the expression of PDGFR $\alpha$ in SSc cells and increases their response to PDGF, suggesting that cross-talk between TGF- $\beta$ and PDGF pathways may regulate chronic fibrosis in SSc [120].

To examine the role of PDGF and TGF- $\beta$ in the pathogenesis of SSc-associated pulmonary fibrosis, PDGF and TGF- $\beta$ levels were determined in bronchoalveolar lavage (BAL) fluid from patients with SSc and healthy controls. BAL fluid from SSc patients was found to contain significantly elevated levels of PDGF-AA, PDGF-BB, and TGF- $\beta 1$ [121]. SSc lung myofibroblasts pretreated with TGF- $\beta 1$ exhibited an enhanced mitogenic effect upon stimulation by PDGF, caused in part by the induction of the PDGF $\alpha$ receptor. These studies support a role for PDGF and TGF- $\beta 1$ in the pathogenesis of SSc lung disease. The potent smooth muscle cell mitogenic effects of PDGF have been implicated in the severe fibroproliferative changes in the pulmonary vasculature occurring during the development of primary pulmonary hypertension [122] and it has been suggested that highly selective tyrosine kinase inhibitors such as imatinib and dasatinib that are capable of abrogating the activation of PDGF receptor tyrosine kinase may be effective therapies for primary pulmonary hypertension and provides support for their use in the treatment of SSc $[119,122-124]$. 
Of substantial interest has been the recent description of the occurrence in the sera of SSc patients of functional anti-PDGF receptor-specific autoantibodies capable of activating and initiating PDGF signaling [125]. In this study, stimulatory antibodies to the PDGFR that were capable of activating collagen-gene expression and inducing the production of reactive oxygen radicals (ROS) in mouse-embryo fibroblasts were found in all the SSc patients studied. The antibodies recognized native PDGFR, inducing tyrosine phosphorylation and ROS accumulation and stimulation of type I collagen-gene expression as well as myofibroblast phenotype conversion in normal human primary fibroblasts. These results suggested that functional antiPDGF antibodies have a causal role in the pathogenesis of SSc [126]. Given the potential importance and significance of these results, several subsequent studies were performed to confirm the presence of functional anti-PDGFR antibodies in patients with SSc. In one study, immunoglobulins (IgGs) from 37 patients with SSc were purified and PDGFR activation tested using 4 different bioassays. Purified IgG samples from patients with SSc were positive when tested for antinuclear autoantibodies, but failed to specifically activate PDGFR $\alpha$ or PDGFR $\beta$ in any of the tests [127]. Another study employed an electrochemiluminescence binding assay for detection of serum autoantibodies to PDGFR $\alpha, \operatorname{PDGFR} \beta$, epidermal growth factor receptor (EGFR), and colony-stimulating factor receptor 1 (CSFR1), and the level of receptor phosphorylation induced by pure Ig was determined by enzyme-linked immunoassay, Western blot, and functional agonist activity mitogenic assay. Although approximately one-third of sera samples from SSc patients contained detectable autoantibodies to PDGFR, these antibodies were not specific to SSc, since they were also detected in a similar percentage of samples from normal subjects. Furthermore, PDGFR $\alpha$ agonist activity was not demonstrated when purified IgG from these sera was tested in cell-based assays [128]. A third study to evaluate the presence of anti- 
PDGFR $\alpha$ antibodies in patients with SSc found non-significant differences between patients with $\mathrm{SSc}$ and controls and there was no correlation between the presence or titers of anti-PDGFR $\alpha$ antibodies and the clinical and serological features of SSc. Furthermore, serum samples from patients with SSc and healthy people recognized the same band corresponding to PDGFR $\alpha$ by immunoblot [129]. Thus, the current evidence is not conclusive and there is substantial controversy and uncertainty about the presence of functional PDGFR $\alpha$ activating antibodies in the sera of SSc patients.

Fibroblast growth factors (FGF). FGF comprise a large family of growth factors which play a crucial role during embryonic development, participating in numerous differentiation processes including mesoderm induction and mesenchymal-epithelial signaling [130,131]. FGF are potent mitogenic factors that have numerous functions in adult organisms such as angiogenesis and wound healing [132]. FGF are secreted glycoproteins produced by a variety of cells which, following secretion, are stored in the extracellular compartment by binding to heparan sulfate proteoglycans. FGF signaling occurs through 4 distinct transmembrane receptor kinases and complex cascades of intracellular reactions that lead to activation or repression of the expression of numerous target genes [133]. Numerous studies have demonstrated the potent fibroblast mitogenic effects of FGF during inflammatory and fibrotic responses. However, the marked increase in cellular proliferation is accompanied by a reduction in expression of collagen and other ECM molecules. Thus, the role of FGF in the pathogenesis of SSc tissue fibrosis is not fully understood.

One recent study examined basic FGF (bFGF) expression in skin biopsies from SSc patients and found increased expression in the epidermis and dermis as compared to normal tissues. However, there was no correlation of the levels of expression with the duration of 
disease or the extent of skin involvement, although some of the results suggested that bFGF may act in an autocrine or paracrine manner in fibrogenesis [134]. In contrast, another study showed that bFGF is a potent inhibitor of basal and TGF- $\beta$ stimulated collagen expression in human fibroblasts, and that this effect was no different in SSc than in healthy fibroblasts [135]. Therefore, the role of FGF in the initiation of progression of the fibrotic process in SSc has not been completely elucidated and additional studies will be required to conclusively determine the contribution of this potent growth factor to the pathogenesis of fibrosis in SSc.

Vascular endothelial growth factor (VEGF). VEGF is an endothelial cell specific growth factor with multiple functions including stimulation of endothelial cell proliferation and differentiation, modulation of endothelial permeability, and potent effects on vascular remodeling [136]. Expression of VEGF is markedly induced by hypoxia and is regulated by hypoxia-inducible factor $1 \alpha$. A recent study suggested that tissue hypoxia in affected skin and other organs of patients with SSc may result in alterations in VEGF regulation and therefore may play an important role in the altered angiogenesis which is a characteristic feature in SSc [137].

Measurement of serum levels of VEGF in patients with SSc and healthy controls showed that serum VEGF levels were significantly higher in SSc patients and correlated well with the extent of skin sclerosis. Serum VEGF levels were also inversely correlated with nailfold capillary density, suggesting that high VEGF levels may participate in the capillary damage in SSc [138]. In another study, serum levels of VEGF were measured in patients with various connective tissue diseases. Patients with diffuse SSc showed elevated VEGF levels in comparison with normal controls. An elevated serum VEGF level was correlated with the frequency of lung fibrosis and reduced vital capacity in the patients with SSc [139]. However, although serum VEGF levels were found to be consistently elevated in SSc patients, the source 
of circulating VEGF was not known. In one study the role of platelets as a source of VEGF and other angiogenic mediators of SSc was examined. The results showed that platelets from SSc patients, in contrast to controls, secreted large amounts of VEGF and suggested that these cells may play an important role in the altered angiogenesis associated with the disease through the secretion of high levels of VEGF [140]. Given the potent proangiogenic effects of VEGF, the role of this growth factor in the pathogenesis of SSc associated fibroproliferative alterations such as pulmonary artery hypertension (PAH) has been the subject of intense investigation. An evaluation of the relationships between pulmonary artery pressure, clinical and functional manifestations of SSc and serum VEGF levels showed that serum VEGF levels were increased in SSc patients with PAH and suggested a possible role of VEGF in the pathogenesis of PAH in SSc [141].

It has been proposed that the disturbed vessel morphology with enlarged capillaries and an overall reduction in capillary density frequently present in SSc may represent an insufficient angiogenic response and that these abnormalities may be due to reduced VEGF expression. However, in refutation of this hypothesis was the observation that the expression of both VEGF and its receptors VEGFR-1 and VEGFR-2 were upregulated in SSc skin. Upregulation of VEGF was likely mediated by an altered expression pattern of various cytokines [142]. Thus, these results do not support the notion that alterations in VEGF signaling are responsible for the occurrence of capillary abnormalities in SSc.

\section{Insulin-like growth factor (IGF) and insulin-like growth factor binding proteins}

(IGFBP). IGFs comprise a family of regulatory polypeptides with high sequence similarity to insulin that are involved in numerous physiologic states including growth and development, cellular proliferation and apoptosis, and aging $[143,144]$. IGFs are part of a complex protein 
network comprising two distinct IGF molecular species (IGF-1 and IGF-2), two cell surface receptors (IGFR1 and IGFR2), and six specific binding proteins (IGFBP1-6). The IGFBPs modulate the function of IGFs by sequestering them with high affinity within the extracellular matrix [145]. Several studies have examined the role of IGFs and IGFBPs in fibrotic conditions including pulmonary fibrosis and SSc. Stimulation of fibroblast proliferation induced by bronchoalveolar lavage from patients with SSc associated pulmonary fibrosis was found to be caused largely by IGF-1 as demonstrated by inhibition with specific antibodies [146]. Supporting the profibrotic role of IGFBP, elevated levels of IGFBP-3 and -5 were found in pulmonary fibrosis [147]. Furthermore, measurements of serum IGF-1 and IGFBP-3 levels in patients with SSc were found to be significantly elevated compared with patients with systemic lupus erythematosus or healthy controls. IGF-1 levels correlated with the extent of skin involvement and the presence of pulmonary fibrosis. Furthermore, IGF-1 mRNA was upregulated in the affected skin of patients with SSc. These results collectively suggested that IGF-1 and IGFBP-3 are involved in the development of fibrosis in SSc [148].

In another study, IGF-2 expression was examined in explanted lung tissues from control and SSc patients to determine its role in the pathogenesis of SSc associated pulmonary fibrosis. Immunostaining revealed increased IGF-2 expression in fibroblastic foci of SSc lungs and cultured primary SSc lung fibroblasts had a fourfold increase in IGF-2 mRNA and a twofold increase in IGF-2 protein compared with normal lung fibroblasts. IGF-2 induced a dose- and time-dependent increase in collagen type I and fibronectin production and triggered the activation of several important kinase pathways including the PI3K signaling cascade. These results provided strong support and novel insights into the role of IGF-2 in the pathogenesis of SSc-associated pulmonary fibrosis [149]. 


\section{Concluding Remarks}

Remarkable recent progress in the understanding of the molecular events involved in the development of SSc tissue fibrosis has allowed the identification of key molecules, key cellular mechanisms, and key intracellular signaling cascades that mediate the initiation and progression of fibrosis in this disorder. Results of these studies have provided novel approaches for the treatment and correction of the molecular alterations involved in the fibrotic component of SSc, among which the most promising appear to include modifiers of TGF- $\beta 1$ activation and signaling, tyrosine kinase inhibitors, and inhibitors of other growth factors involved in the fibrotic process [48,51,150]. Many of these approaches have already been confirmed by extensive clinical and preclinical evidence and it is likely that they will be available for clinical use in the near future. Furthermore, it is expected that given the strong molecular rationale for their use these novel therapies will be highly effective in controlling and reversing the severe clinical manifestations of the fibrotic process in SSc.

\section{Acknowledgements}

Supported by NIH Grant RO1AR019616 to SAJ.

\section{Disclosure}

The authors disclose no competing interests. 


\section{References}

1. Jimenez SA, Derk CT. Following the molecular pathways toward an understanding of the pathogenesis of Systemic Sclerosis. Ann Int Med 2004; 140: 37-50.

2. Varga J, Abraham D. Systemic sclerosis: a prototypic multisystem fibrotic disorder. J Clin Invest 2007; 117: 557-67.

3. Denton CP, Black CM, Abraham DJ. Mechanisms and consequences of fibrosis in systemic sclerosis. Nat Clin Pract Rheumatol 2006; 2: 134-44.

4. Gabrieli A, Avvediemento EV, Krieg T. Mechanisms of Disease: Scleroderma. N Engl J Med 2009; 360; 1989-2003.

5. Jimenez SA, Hitraya E, Varga J. Pathogenesis of scleroderma. Collagen. Rheum Dis Clin North Am 1996; 22: 647-74.

6. Trojanowska M. Molecular aspects of scleroderma. Front Biosci 2002; 7: c608-18.

7. Kissin EY, Korn JH. Fibrosis in scleroderma. Rheum Dis Clin North Am 2003; 29: 351-69.

8. Varga JA, Trojanowska M. Fibrosis in systemic sclerosis. Rheum Dis Clin North Am 2008; 34: 115-43.

9. LeRoy EC. Connective tissue synthesis by scleroderma skin fibroblasts in cell culture. J Exp Med 1972; 135: 1351-1352.

10. Strehlow D, Korn JH. Biology of the scleroderma fibroblast. Curr Opin Rheumatol 1998; 10: 572-8.

11. Eyden B. The myofibroblast: phenotypic characterization as a prerequisite to understanding its functions in translational medicine. J Cell Mol Med 2008; 12: 22-37.

12. Kalluri R, Nielson EG. Epithelial-mesenchymal transitions and it implications for fibrosis. $\mathbf{J}$ Clin Invest 2003; 112: 1776-84.

13. Kalluri R, Weinberg RA. The basics of epithelial-mesenchymal transition. J Clin Invest 2009; 119: 1420-8.

14. Thiery JP, Acloque H, Huang RY, Nieto MA. Epithelial-mesenchymal transitions in development and disease. Cell 2009; 139: 871-90.

15. Postlethwaite AE, Shigemitsu H, Kanangat S. Cellular origins of fibroblasts: possible implications for organ fibrosis in systemic sclerosis. Curr Opin Rheumatol 2004; 16: 733-8.

16. Botstein GR, Sherer GK, LeRoy EC. Fibroblast selection in scleroderma. An alternative model of fibrosis. Arthritis Rheum 1982; 25:189-95. 
17. Jelaska A, Korn JH. Role of apoptosis and transforming growth factor beta1 in fibroblast selection and activation in systemic sclerosis. Arthritis Rheum 2000; 43: 2230-9.

18. Bucala R, Spiegel LA, Chesney J, Hogan M, Cerami A. Circulating fibrocytes define a new leukocyte subpopulation that mediates tissue repair. Mol Med 1994; 1: 71-81.

19. Quan TE, Cowper S, Wu SP, Bockenstedt LK, Bucala R. Circulating fibrocytes: collagensecreting cells of the peripheral blood. Int J Biochem Cell Biol 2005; 36: 598-606.

20. Quan TE, Cowper SE, Bucala R. The role of circulating fibrocytes in fibrosis. Curr Rheumatol Rep 2006; 8: 145-50.

21. Abraham DJ, Eckes B, Rajkumar V, Krieg T. New developments in fibroblast and myofibroblast biology: implications for fibrosis and scleroderma. Curr Rheumatol Rep 2007; 9: 136-43.

22. Zeisberg EM, Tarnavski O, Zeisberg M, dorfman AL, McMullen JR, Gustafsson E, Chandraker A, Yuan X, Pu WT, Roberts AB, Neilson EG, Sayegh MH, Izumo S, Kalluri R. Endothelial-to-mesenchymal transition contributes to cardiac fibrosis Nat Med 2007; 13 : 952-61.

23. Zeisberg EM, Potenta SE, Sugimoto H, Zeisberg M, Kalluri R. Fibroblasts in kidney fibrosis emerge via endothelial-to-mesenchymal transition J Am Soc Nephrol 2008; 19: 2282-7.

24. Hashimoto N, Phan SH, Imaizumi K, Matsuo M, Nakashima H, Kawabe T, Shimokata K, Hasegawa Y. Endothelial-mesenchymal transition in bleomycin-induced pulmonary fibrosis. Am J Respir Cell Mol Biol 2009 Sep 18 [Epub ahead of print].

25. Roberts AB, Sporn MB. Transforming growth factor beta. Adv Cancer Res 1988; 51: 107-45.

26. Roberts AB, Flanders KC, Kondaiah P, Thompson NL, Van Obberghen-Schilling E, Wakefield L, Rossi P, de Crombrugghe B, Heine U, Sporn MB. Transforming growth factor beta: biochemistry and roles in embryogenesis, tissue repair and remodeling, and carcinogenesis. Recent Prog Horm Res. 1988; 44: 157-97.

27. Massague J, Cheifetz S, Ignotz RA, Boyd FT. Multiple type-beta transforming growth factors and their receptors. J Cell Physiol 1987; 5: s43-7.

28. Miyazono K, Olofsson, A, Colosetti P, Heldin CH. A role of the latent TGF-beta 1-binding protein in the assembly and secretion of TGF-beta 1. EMBO J 1991; 10: 1091-101.

29. Taipale J, Miyazono K, Heldin CH, Keski-Oja J. Latent transforming growth factor-beta 1 associates to fibroblast extracellular matrix via latent TGF-beta binding protein. J Cell Biol 1994; 124: 171-81.

30. Murphy-Ullrich JE, Poczatek M. Activation of latent TGF-beta by thrombospondin-1: mechanisms and physiology. Cytokine Growth Factor Rev 2000; 11: 59-69. 
31. Sheppard D. Integrin-mediated activation of latent transforming growth factor beta. Cancer Metastasis Rev 2005; 24: 395-402.

32. Massague J. How cells read TGF-beta signals. Nat Rev Mol Cell Biol 2000; 1: 169-78.

33. Attisano L, Wrana JL. Signal transduction by the TGF-beta superfamily. Science 2002; 296: 1646-7.

34. Derynck R, Zhang YE. Smad-dependent and Smad-independent pathways in TGF $\beta$ family signalling. Nature 2003; 425: 577-84.

35. Ten Dijke P, Hill CS. New insights into TGF- $\beta-$ Smad signaling. Trends Biochem 2004; 29 : 265-74.

36. Varga J. Scleroderma and Smads: dysfunctional Smad family dynamics culminating in fibrosis. Arthrits Rheum 2002; 46: 1703-1713.

37. Ross S, Hill CS. How the Smads regulate transcription. Int J Biochem Cell Biol 2008; 40: 383-408.

38. Pannu J, Nakerakanti S, Smith E, ten Dijke P, Trojanowska M. Transforming growth factorbeta receptor type I-dependent fibrogenic gene program is mediated via activation of Smad1 and ERK1/2 pathways. J Biol Chem 2007; 282: 10405-13.

39. Massague J, Chen YG. Controlling TGF-beta signaling. Genes Dev 2000; 14: 627-44.

40. Nakao A, Afrakhte M, Moren A, Nakayama T, Christian JL, Heuchel R, Itoh S, Kawabata M, Heldin NE, Heldin CH, ten Dijke P. Identification of Smad7, a TGFbeta-inducible antagonist of TGF-beta signaling. Nature 1997; 389: 631-5.

41. Hayashi H, Abdollah S, Qiu Y, Cai J, Xu YY, Grinnell BW, Richardson Ma, Topper JN, Gimbrone MA Jr, Wrana JL, Falb D. The MAD-related protein Smad7 associates with the TGFbeta receptor and functions as an antagonist of TGFbeta signaling. Cell 1997; 89: 116573.

42. Kavsak P. Rasmussen RK, Causing CG, Bonni S, Zhu H, Thomsen GH, Wrana JL. Smad7 binds to Smurf 2 to form an E3 ubiquitin ligase that targets the TGF- $\beta$ receptor for degradation. Mol. Cell. 2000;6:1365-1375.

43. Moustakas A, Heldin C-H. Non-Smad TGF- $\beta$ signals. J Cell Sci 2005; 118: 3573-84.

44. Zhang YE. Non-Smad pathways in TGF-beta signaling. Cell Res 2009; 19: 128-139.

45. Bhattachavya S, Ishida W, Wu M, Wilkes M, Mori Y, Hinchcliff M, Leof E, Varga J. A nonSmad mechanism of fibroblast activation by transforming growth factor-beta via c-Abl and Egr-1: selective modulation by imatinib mesylate. Oncogene 2009 Jan 19. (Epub ahead of print). 
46. Pendergast AM, Witte ON. Role of the ABL oncogene tyrosine kinase activity in human leukaemia. Baillieres Clin Haematol 1987; 1: 1001-20.

47. Goldman JM, Melo JV. BCR-ABL in chronic myelogenous leukemia - how does it work? Acta Haematol 2008; 119: 212-7.

48. Rosenbloom J, Jimenez SA. Molecular ablation of TGF- $\beta$ signaling pathways by tyrosine kinase inhibition: the coming of a promising new era in the treatment of tissue fibrosis. Arthritis Rheum 2008; 58: 2219-24.

49. Pannu J, Asano Y, Nakerakanti S, Smith E, Jablonska S, Blaszczyk M, ten Dijke P, Trojanowska M. Smad1 pathway is activated in systemic sclerosis fibroblasts and is targeted by imatinib mesylate. Arthritis Rheum. 2008; 58: 2528-37.

50. Castelino FV, Bhattacharyya S, Varga J. Tyrosine kinase inhibitors in systemic sclerosis: the case for imatinib.

51. Rosenbloom J, Castro SV, Jimenez SA. Fibrotic Diseases: Cellular and Molecular Mechanisms and Novel Therapies. (Physiology in Medicine Series). Ann Int Med 2010; 152: $159-67$.

52. Bibi Y, Gottlieb AB.A potential role for imatinib and other small molecule tyrosine kinase inhibitors in the treatment of systemic and localized sclerosis. J Am Acad Dermatol 2008; 59: 654-8.

53. Chung L, Fiorentino DF, Benbarak MJ, Adler AS, Mariano MM, Paniagua RT, Milano A, Connolly MK, Ratiner BD, Wiskocil RL, Whitfield ML, Chang HY, Robinson WH. Molecular framework for response to imatinib mesylate in systemic sclerosis. Arthritis Rheum 2009; 60: 584-91.

54. Downes CP, Carter AN. Phosphoinositide 3-kinase: a new effector in signal transduction? Cell Signal 1991; 3: 501-13.

55. Franke TF. PI3K/Akt: getting it right matters. Oncogene 2008; 27: 6473-88.

56. Bujor AM, Pannu J, Bu S, Smith EA, Muise-Helmericks RC, Trojanowska M. Akt blockade downregulates collagen and upregulates MMP1 in human dermal fibroblasts. J Invest Dermatol 2008; 128: 1906-14.

57. Jun JB, Kuechle M, Min J, Shim SC, Kim G, Montenegro V, Korn JH, Elkon KB. Scleroderma fibroblasts demonstrate enhanced activation of Akt (protein kinase B) in situ. J Invest Dermatol 2005; 124: 298-303.

58. Chiang TM, Postlethwaite AE. Alteration in protein kinase B (AKT) activity in platelets form patients with systemic sclerosis. Thromb Res 2008; 122: 501-6. 
59. Jimenez SA, Gaidarova S, Saitta B, Sandorfi N, Herrich DJ, Rosenbloom JC, Kucich U, Abrams WR, Rosenbloom J. Role of protein kinase C-delta in the regulation of collagen gene expression in scleroderma fibroblasts. J Clin Invest 2001; 108: 1395-403.

60. Jinnin M, Ihn H, Yamane K, Mimuar Y, Asano Y, Tamaki K. Alpha1(I) collagen gene regulation by protein kinase $\mathrm{C}$ signaling in human dermal fibroblasts. Nucleic Acids Res 2005; 33: 1337-51.

61. Asano Y, Trojanowska M. Phosphorylation of Fli1 at threonine 312 by protein kinase C delta promotes its interaction with $\mathrm{p} 300 / \mathrm{CREB}$-binding protein-associated factor and subsequent acetylation in response to transforming growth factor beta. Mol Cell Biol 2009; 29: 1882-94.

62. Di Guglielmo GM, Le Roy C, Goodfellow AF, Wrana JL. Distinct endocytic pathways regulate TGF-beta receptor signalling and turnover. Nat Cell Biol 2003; 5: 410-21.

63. Hayes S, Chawla A, Corvera S. TGF beta receptor internalization into EEA1-enriched early endosomes: role in signaling to Smad2. J Cell Biol 2002; 158: 1239-1249.

64. Runyan CE, Schnaper HW, Poncelet AC. The role of internalization in transforming growth factor beta1-induced Smad2 association with Smad anchor for receptor activation (SARA) and Smad2-dependent signaling in human mesangial cells. J Biol Chem 2005; 280:83008308 .

65. Del Galdo F, Lisanti MP, Jimenez SA. Caveolin-1, transforming growth factor-beta receptor internalization, and the pathogenesis of systemic sclerosis. Curr Opin Rheumatol 2008; 20: 713-9.

66. Del Galdo F, Sotgia F, de Almeida CJ, Jasmin JF, Musick M, Lisanti MP, Jiménez SA. Decreased expression of caveolin 1 in patients with systemic sclerosis: crucial role in the pathogenesis of tissue fibrosis. Arthritis Rheum 2008; 58: 2854-65.

67. Tourkina E, Richard M, Gööz P, Bonner M, Pannu J, Harley R, Bernatchez PN, Sessa WC, Silver RM, Hoffman S. Antifibrotic properties of caveolin-1 scaffolding domain in vitro and in vivo.

68. Le Saux O, Teeters K, Miyasato S, Choi J, Nakamatsu G, Richardson JA, Starcher B, Davis EC, Tam EK, Jourdan-Le Saux C. The role of caveolin-1 in pulmonary matrix remodeling and mechanical properties. Am J Physiol Lung Cell Mol Physiol 2008; 295: L1007-17.

69. Border WA, Noble NA. Transforming growth factor beta in tissue fibrosis. N Engl J Med 1994; 331: 1286-92.

70. Blobe GC, Schiemann WP, Lodish HF. Role of transforming growth factor beta in human disease. N Engl J Med 2000; 342: 1350-8.

71. Goumans MJ, Liu Z, ten Dijke P. TGF-beta signaling in vascular biology and dysfunction. Cell Res 2009; 19: 116-27. 
72. Prud'homme GJ. Pathobiology of transforming growth factor beta in cancer, fibrosis and immunologic disease, and therapeutic considerations. Lab Invest 2007; 87: 1077-91.

73. Smith EA, LeRoy EC. A possible role for transforming growth factor-beta in systemic sclerosis. J Invest Dermatol 1990; 95: 125S-127S.

74. Peltonen J, Kähäri L, Jaakkola S, Kähäri VM, Varga J, Uitto J, Jimenez SA. Evaluation of transforming growth factor beta and type I procollagen gene expression in fibrotic skin diseases by in situ hybridization. J Invest Dermatol 1990; 94: 365-71.

75. Gruschwitz M, Müller PU, Sepp N, Hofer E, Fontana A, Wick G. Transcription and expression of transforming growth factor type beta in the skin of progressive systemic sclerosis: a mediator of fibrosis? J Invest Dermatol 1990; 94: 197-203.

76. Ihn H. Pathogenesis of fibrosis: role of TGF-beta and CTGF. Curr Opin Rheumatol 2002; 14: 681-5.

77. Leask A, Abraham DJ. TGF-beta signaling and the fibrotic response. FASEB J 2004; 18 : 816-27.

78. Roberts AB, Sporn MB, Assoian RK, Smith JM, Roche NS, Wakefield LM, Heine UI, Liotta LA, Falanga V, Kehrl JH, et al. Transforming growth factor type beta: rapid induction of fibrosis and angiogenesis in vivo and stimulation of collagen formation in vitro. Proc Natl Acad Sci U S A 1986; 83: 4167-71

79. Ignotz RA, Massagué J. Transforming growth factor-beta stimulates the expression of fibronectin and collagen and their incorporation into the extracellular matrix. J Biol Chem 1986; 261: 4337-45.

80. Varga J, Jimenez SA. Stimulation of normal human fibroblast collagen production and processing by transforming growth factor-beta. Biochem Biophys Res Commun 1986; 138 : 974-80.

81. Varga J, Rosenbloom J, Jimenez SA. Transforming growth factor beta (TGF beta) causes a persistent increase in steady-state amounts of type I and type III collagen and fibronectin mRNAs in normal human dermal fibroblasts. Biochem J 1987; 247: 597-604.

82. Raghow R, Postlethwaite AE, Keski-Oja J, Moses HL, Kang AH. Transforming growth factor-beta increases steady state levels of type I procollagen and fibronectin messenger RNAs posttranscriptionally in cultured human dermal fibroblasts. J Clin Invest 1987; 791 : 285-8.

83. Roberts AB, Heine UI, Flanders KC, Sporn MB. Transforming growth factor-beta. Major role in regulation of extracellular matrix. Ann N Y Acad Sci 1990; 580: 225-32.

84. McAnulty RJ, Campa JS, Cambrey AD, Laurent GJ. The effect of transforming growth factor beta on rates of procollagen synthesis and degradation in vitro. Biochim Biophys Acta 1991; 1091: 231-5. 
85. Edwards DR, Murphy G, Reynolds JJ, Whitham SE, Docherty AJ, Angel P, Heath JK. Transforming growth factor beta modulates the expression of collagenase and metalloproteinase inhibitor. EMBO J 1987; 6: 1899-904.

86. Van Obberghen-Schilling E, Roche NS, Flanders KC, Sporn MB, Roberts AB. Transforming growth factor beta 1 positively regulates its own expression in normal and transformed cells. J Biol Chem 1988; 263: 7741-6.

87. Pannu J, Gardner H, Shearstone JR, Smith E, Trojanowska M. Increased levels of transforming growth factor beta receptor type I and up-regulation of matrix gene program: A model of scleroderma. Arthritis Rheum 2006; 54: 3011-21.

88. Willis BC, Borok Z. TGF-beta-induced EMT: mechanisms and implications for fibrotic lung disease. Am J Physiol Lung Cell Mol Physiol 2007; 293: L525-34.

89. Potts JD, Runyan RB. Epithelial-mesenchymal cell transformation in the embryonic heart can be mediated, in part, by transforming growth factor beta. Dev Biol 1989; 134: 392-401.

90. Dziadzio M, Smith RE, Abraham DJ, Black CM, Denton CP. Circulating levels of active transforming growth factor beta 1 are reduced in diffuse cutaneous systemic sclerosis and correlate inversely with the modified Rodnan skin score. Rheumatology (Oxford) 2005; 44: 1518-24.

91. Ota H, Kumagai S, Morinobu A, Yanagida H, Nakao K. Enhanced production of transforming growth factor-beta (TGF- $\beta$ ) during autologous mixed lymphocyte reaction of systemic sclerosis patients. Clin Exp Immunol 1995; 100: 99-103.

92. Hasegawa M, Sato S, Takehara K. Augmented production of TGF- $\beta$ by cultured peripheral blood mononuclear cells from patients with systemic sclerosis. Arch Dermatol Res 2004; 296: 89-93.

93. Ihn H, Yamane K, Kubo M, Tamaki K. Blockade of endogenous transforming growth factor beta signaling prevents up-regulated collagen synthesis in scleroderma fibroblasts: association with increased expression of transforming growth factor beta receptors. Arthritis Rheum 2001; 44: 474-80.

94. Asano Y, Ihn H, Yamane K, Jinnin M, Mimura Y, Tamaki K. Involvement of alphavbeta5 integrin-mediated activation of latent transforming growth factor beta1 in autocrine transforming growth factor beta signaling in systemic sclerosis fibroblasts. Arthritis Rheum 2005; 52: 2897-905.

95. Kubo M, Ihn H, Yamane K, Tamaki K. Upregulated expression of transforming growth factor-beta receptors in dermal fibroblasts of skin sections from patients with systemic sclerosis. J Rheumatol 2002; 29: 2558-64

96. Mori Y, Ishida W, Bhattacharyya S, Li Y, Platanias LC, Varga J. Selective inhibition of activin receptor-like kinase 5 signaling blocks profibrotic transforming growth factor beta responses in skin fibroblasts. Arthritis Rheum 2004; 50: 4008-21. 
97. Chen Y, Shi-wen X, Eastwood M, Black CM, Denton CP, Leask A, Abraham DJ. Contribution of activin receptor-like kinase 5 (transforming growth factor beta receptor type I) signaling to the fibrotic phenotype of scleroderma fibroblasts. Arthritis Rheum 2006; 54: 1309-16.

98. Verrecchia F, Mauviel A, Farge D. Transforming growth factor-beta signaling through the Smad proteins: role in systemic sclerosis. Autoimmun Rev 2006; 5: 563-9.

99. Dong C, Zhu S, Wang T et al. Deficient Smad 7 expression: a putative molecular defect in scleroderma. Proc Natl Acad Sci U S A 2002; 99: 3908-13.

100. Mori, Y, Chen SJ, Varga J. Expression and regulation of intracellular SMAD signaling in scleroderma skin fibroblasts. Arthritis Rheum 2003; 48: 1964-78.

101. Ihn H, Yamane K, Asano Y, Jinnin M, Tamaki K. Constitutively phosphorylated Smad3 interacts with Sp1 and p300 in scleroderma fibroblasts. Rheumatology (Oxford) 2006; 45: 157-65.

102. Sato M, Shegogue D, Gore EA, Smith EA, McDermott PJ, Trojanowska M. Role of p38 MAPK in transforming growth factor beta stimulation of collagen production by scleroderma and healthy dermal fibroblasts. J Invest Dermatol 2002; 118: 704-11.

103. Bhattacharyya S, Ghosh AK, Pannu J, Mori Y, Takagawa S, Chen G, Trojanowska M, Gilliam AC, Varga J. Fibroblast expression of the coactivator p300 governs the intensity of profibrotic response to transforming growth factor beta. Arthritis Rheum 2005; 52: 124858.

104. Sargent JL, Milano A, Bhattacharyya S, Varga J, Connolly MK, Chang HY, Whitfield ML. A TGFbeta-responsive gene signature is associated with a subset of diffuse scleroderma with increased disease severity. J Invest Dermatol 2010; 130: 694-705.

105. Grotendorst GR. Connective tissue growth factor: a mediator of TGF-beta action on fibroblasts. Cytokine Growth Factor Rev 1997; 8: 171-9.

106. Leask A, Abraham DJ. The role of connective tissue growth factor, a multifunctional matricellular protein, in fibroblast biology. Biochem Cell Biol 2003; 81: 355-63.

107. Leask A, Abraham DJ. All in the CCN family: essential matricellular signaling modulators emerge from the bunker. J Cell Sci 2006; 119: 4803-10.

108. Shi-Wen X, Leask A, Abraham D. Regulation and function of connective tissue growth factor/CCN2 in tissue repair, scarring and fibrosis. Cytokine Growth Factor Rev 2008; 19: 113-44.

109. Leask A, Denton CP, Abraham DJ. Insights into the molecular mechanism of chronic fibrosis: the role of connective tissue growth factor in scleroderma. J Invest Dermatol 2004; 122: $1-6$. 
110. Denton CP, Abraham DJ. Transforming growth factor-beta and connective tissue growth factor: key cytokines in scleroderma pathogenesis. Curr Opin Rheumatol 2001; 13: 505-11.

111. Sato S, Nagaoka T, Hasegawa M, Tamatani T, Nakanishi T, Takigawa M, Takehara K. Serum levels of connective tissue growth factor are elevated in patients with systemic sclerosis: association with extent of skin sclerosis and severity of pulmonary fibrosis. $\mathbf{J}$ Rheumatol 2000; 27: 149-54.

112. Igarashi A, Nashiro K, Kikuchi K, Sato S, Ihn H, Grotendorst GR, Takehara K. Significant correlation between connective tissue growth factor gene expression and skin sclerosis in tissue sections from patients with systemic sclerosis. J Invest Dermatol 1995; 105: 280-4.

113. Bogatkevich GS, Ludwicka-Bradley A, Singleton CB, Bethard JR, Silver RM Proteomic analysis of CTGF-activated lung fibroblasts: identification of IQGAP1 as a key player in lung fibroblast migration. Am J Physiol Lung Cell Mol Physiol 2008; 295: L603-11.

114. Ross R, Bowen-Pope DF, Raines EW. Platelet-derived growth factor and its role in health and disease. Philos Trans R Soc Lond B Biol Sci 1990; 327: 155-69.

115. Rosenkranz S, Kazlauskas A. Evidence for distinct signaling properties and biological responses induced by the PDGF receptor alpha and beta subtypes. Growth Factors 1999; 16: 201-16.

116. Andrae J, Gallini R, Betsholtz C. Role of platelet-derived growth factors in physiology and medicine. Genes Dev 2008; 22: 1276-312.

117. Ostman A, Heldin $\mathrm{CH}$. Involvement of platelet-derived growth factor in disease: development of specific antagonists. Adv Cancer Res 2001; 80: 1-38.

118. Bonner JC. Regulation of PDGF and its receptors in fibrotic diseases. Cytokine Growth Factor Rev 2004; 15: 255-73.

119. Trojanowska M. Role of PDGF in fibrotic diseases and systemic sclerosis. Rheumatology (Oxford) 2008; 47 Suppl 5: v2-4.

120. Yamakage A, Kikuchi K, Smith EA, LeRoy EC, Trojanowska M. Selective upregulation of platelet-derived growth factor alpha receptors by transforming growth factor beta in scleroderma fibroblasts. J Exp Med 1992; 175: 1227-34.

121. Ludwicka A, Ohba T, Trojanowska M, Yamakage A, Strange C, Smith EA, Leroy EC, Sutherland S, Silver RM. Elevated levels of platelet derived growth factor and transforming growth factor-beta 1 in bronchoalveolar lavage fluid from patients with scleroderma. J Rheumatol 1995; 22: 1876-83.

122. Barst RJ. PDGF signaling in pulmonary arterial hypertension. J Clin Invest 2005; 115 : 2691-4. 
123. Grimminger F, Schermuly RT. PDGF receptor and its antagonists: role in treatment of PAH. Adv Exp Med Biol 2010; 661: 435-46.

124. Chhina MK, Nargues W, Grant GM, Nathan SD. Evaluation of imatinib mesylate in the treatment of pulmonary arterial hypertension. Future Cardiol 2010; 6: 19-35.

125. Baroni SS, Santillo M, Bevilacqua F, Luchetti M, Spadoni T, Mancini M, Fraticelli P, Sambo P, Funaro A, Kazlauskas A, Avvedimento EV, Gabrielli A. Stimulatory autoantibodies to the PDGF receptor in systemic sclerosis. N Engl J Med 2006; 354: 266776.

126. Gabrielli A, Svegliati S, Moroncini G, Avvedimento EV. Pathogenic autoantibodies in systemic sclerosis. Curr Opin Immunol 2007; 19: 640-5.

127. Classen JF, Henrohn D, Rorsman F, Lennartsson J, Lauwerys BR, Wikström G, Rorsman C, Lenglez S, Franck-Larsson K, Tomasi JP, Kämpe O, Vanthuyne M, Houssiau FA, Demoulin JB. Lack of evidence of stimulatory autoantibodies to platelet-derived growth factor receptor in patients with systemic sclerosis. Arthritis Rheum 2009; 60: 1137-44.

128. Loizos N, Lariccia L, Weiner J, Griffith H, Boin F, Hummers L, Wigley F, Kussie P. Lack of detection of agonist activity by antibodies to platelet-derived growth factor receptor alpha in a subset of normal and systemic sclerosis patient sera. Arthritis Rheum 2009; 60: 1145-51.

129. Balada E, Simeón-Aznar CP, Ordi-Ros J, Rosa-Leyva M, Selva-O'Callaghan A, PardosGea J, Fonollosa-Pla V, Vilardell-Tarrés M. Anti-PDGFR- $\alpha$ antibodies measured by nonbioactivity assays are not specific for systemic sclerosis. Ann Rheum Dis 2008; 67: 1027-9.

130. Gospodarowicz D, Neufeld G, Schweigerer L. Fibroblast growth factor: structural and biological properties. J Cell Physiol Suppl 1987; S 5: 15-26

131. Klagsbrun M. The fibroblast growth factor family: structural and biological properties. Prog Growth Factor Res 1989; 1: 207-35.

132. Barrientos S. Stojadinovic O, Golinko MS, Brem H, Tomic-Canic M. Growht factors and cytokines in wound healing. Wound Repair Regen 2008; 16: 585-601.

133. Powers CJ, McLeskey SW, Wellstein A. Fibroblast growth factors, their receptors and signaling. Endocr Relat Cancer 2000; 7: 165-97.

134. Lawrence A, Khanna D, Misra R, Aggarwal A. Increased expression of basic fibroblast growth factor in skin of patients with systemic sclerosis. Dermatol Online J 2006; 12: 2 .

135. Ichiki Y, Smith EA, LeRoy EC, Trojanowska M. Basic fibroblast growth factor inhibits basal and transforming growth factor-beta induced collagen $\alpha 2$ (I) gene expression in scleroderma and normal fibroblasts. J Rheumatol 1997; 24: 90-5. 
136. Ferrara N, Davis-Smyth T. The biology of vascular endothelial growth factor. Endocr Rev 1997; 18: 4-25.

137. Beyer C, Schett G, Gay S, Distler O, Distler JH. Hypoxia. Hypoxia in the pathogenesis of systemic sclerosis. Arthritis Rheum 2009; 11: 220.

138. Choi JJ, Min DJ, Cho ML, Min SY, Kim SJ, Lee SS, Park KS, Seo YI, Kim WU, Park SH, Cho CS. Elevated vascular endothelial growth factor in systemic sclerosis. J Rheumatol 2003; 30: 1529-33.

139. Kikuchi K, Kubo M, Kadono T, Yazawa N, IHN H, Tamaki K. Serum concentrations of vascular endothelial growth factor in collagen diseases. Br J Dermatol 1998; 139: 1049-51.

140. Solanilla A, Villeneuve J, Auguste P, Hugues M, Alioum A, Lepreux S, Ducroix JP, Duhaut P, Conri C, Viallard JF, Nurden AT, Constans J, Ripoche J. The transport of high amounts of vascular endothelial growth factor by blood platelets underlines their potential contribution in systemic sclerosis angiogenesis. Rheumatology (Oxford) 2009; 48: 103644.

141. Papaioannou AI, Zakynthinos E, Kostikas K, Kiropoulos T, Koutsokera A, Ziogas A, Koutroumpas A, Sakkas L, Gourgoulianis KI, Daniil ZD. Serum VEGF levels are related to the presence of pulmonary arterial hypertension in systemic sclerosis. BMC Pulm Med 2009; 9: 180 .

142. Distler O, Distler JH, Scheid A, Acker T, Hirth A, Rethage J, Michel BA, Gay RE, MüllerLadner U, Matucci-Cerinic M, Plate KH, Gassmann M, Gay S. Uncontrolled expression of vascular endothelial growth factor and its receptors leads to insufficient skin angiogenesis in patients with systemic sclerosis. Circ Res 2004; 95: 109-16.

143. Cohick WS, Clemmons DR. The insulin-like growth factors. Ann Ref Physiol 1993; 55: 131-53.

144. Froesch ER, Schmid C, Schwander J, Zapf J. Actions of insulin-like growth factors. Annu Rev Physiol 1985; 47: 443-67.

145. Baxter RC, Martin JL. Binding proteins for the insulin-like growth factors: structure, regulation and function. Prog Growth Factor Res 1989; 1: 49-68.

146. Harrison NK, Cambrey AD, Myers AR, Southcott AM, Black CM, du Bois RM, Lourent GJ, McAnulty RJ. Insulin-like growth factor-I is partially responsible for fibroblast proliferation induced by bronchoalveolar lavage fluid from patients with systemic sclerosis. Clin Sci (Lond) 1994; 86: 141-8.

147. Pilewski JM, Liu L, Henry AC, Knauer AV, Feghali-Bostwick Ca. Insulin-like growth factor binding proteins 3 and 5 are overexpressed in idiopathic pulmonary fibrosis and contribute to extracellular matrix deposition. Am J Pathol 2005; 166: 399-407. 
148. Hamaguchi Y, Fujimoto M, Matsushita T, Hasegawa M, Takehara K, Sato S. Elevated serum insulin-like growth factor (IGF-1) and IGF binding protein-3 levels in patients with systemic sclerosis: possible role in development of fibrosis. J Rheumatol 2008; 35: 236371.

149. Hsu E, Feghali-Bostwick CA. Insulin-like growth factor-II is increased in systemic sclerosis-associated pulmonary fibrosis and contributes to the fibrotic process via Jun Nterminal kinase- and phosphatidylinositol-3 kinase-dependent pathways. Am J Pathol 2008; 172: $1580-90$.

150. Distler J, Distler O. Novel treatment approaches to fibrosis in scleroderma. Rheum Dis Clin North Am 2008; 34: 145-59; vii. 


\section{Figure Legends}

Figure 1. Transforming growth factor beta (TGF- $\beta$ ) signaling pathways critical for the fibrotic response. Illustrated are several profibrotic pathways initiated by TGF- $\beta$ binding in fibroblastic cells. Following TGF- $\beta$ binding, the T $\beta$ RII receptor recruits either ALK-1 or ALK-5 type I receptor (TßRI) and activates it by phosphorylation. ALK-5 then specifically phosphorylates receptor-regulated Smad-2 and Smad-3 whereas ALK-1 phosphorylates Smad-1. The receptor Smads, Smad2 or Smad3, then complex with Co-Smad-4 resulting in their transport to the nucleus where they regulate transcription of critical genes, here represented by CTGF, $\alpha 1(\mathrm{I})$, and $\alpha 2(\mathrm{I})$ collagen. Also illustrated are three non-Smad pathways (c-Abl, PKC- $\delta$ and Akt/PKB). One of the two PI3K pathways activates c-Abl, whereas the other activates $\mathrm{Akt} / \mathrm{PKB}$, an important mediator participating in myofibroblast differentiation through EMT as well as through increasing cellular proliferation and survival via its inhibitory effects on cellular apoptosis.

Figure 2. Model for involvement of caveolae in TGF- $\beta$ signal transduction and downregulation. Following ligand binding and receptor activation, activated TGF- $\beta$ receptors can be internalized through two distinct endocytic pathways. The non-lipid raft pathway (green) results in increased TGF- $\beta$ signal transduction, leading to tissue fibrosis and at the same time to transcriptional downregulation of caveolin-1 (cav-1) gene expression. The decrease in caveolin-1 expression generates a vicious cycle that both increases and perpetuates tissue fibrosis. In contrast, the caveolin-1 positive lipid raft compartment (red), drives TGF- $\beta$ receptor proteasomal degradation, leading to abrogation of the fibrotic response. Reproduced from Reference 51. 


\section{Figure 1}

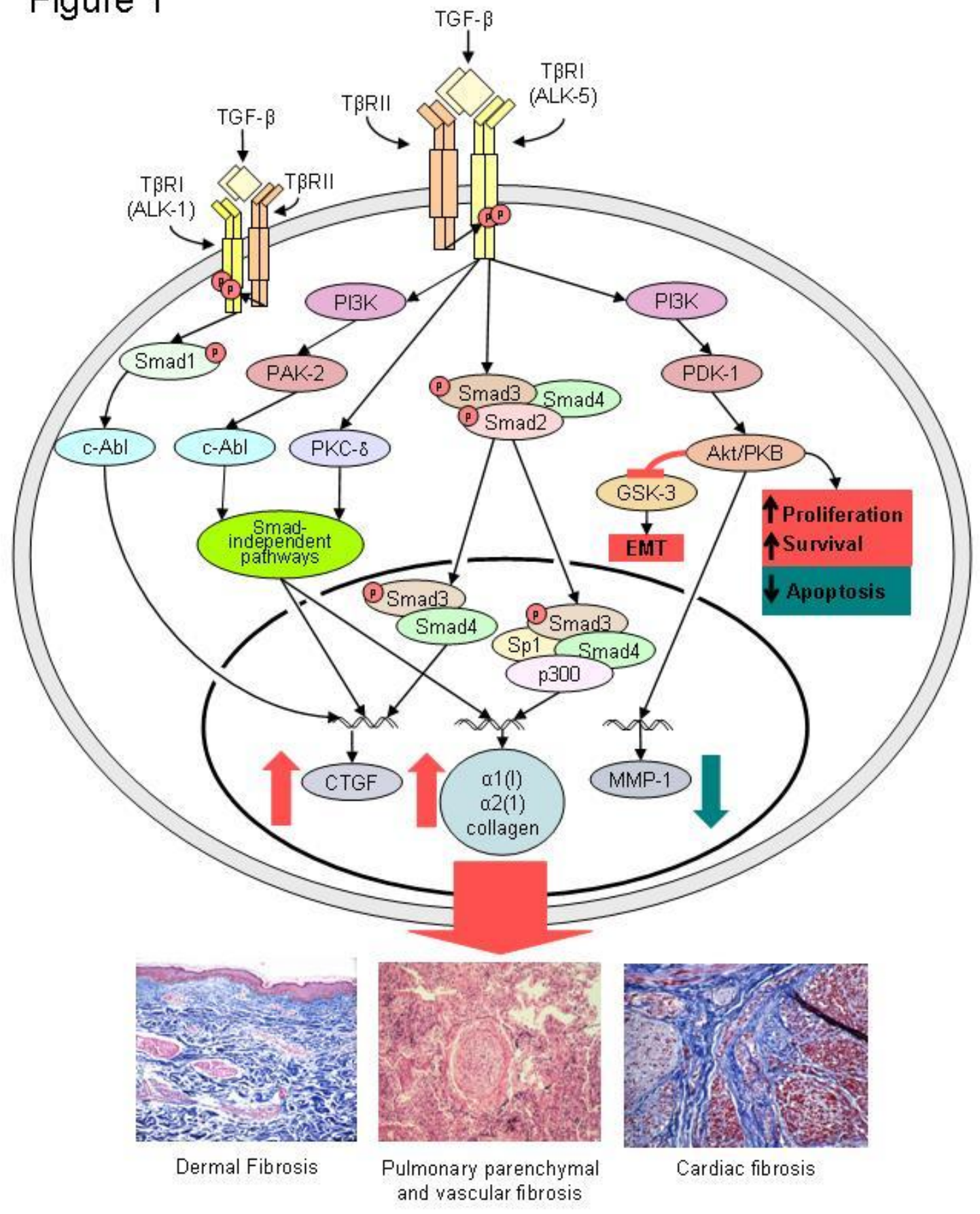




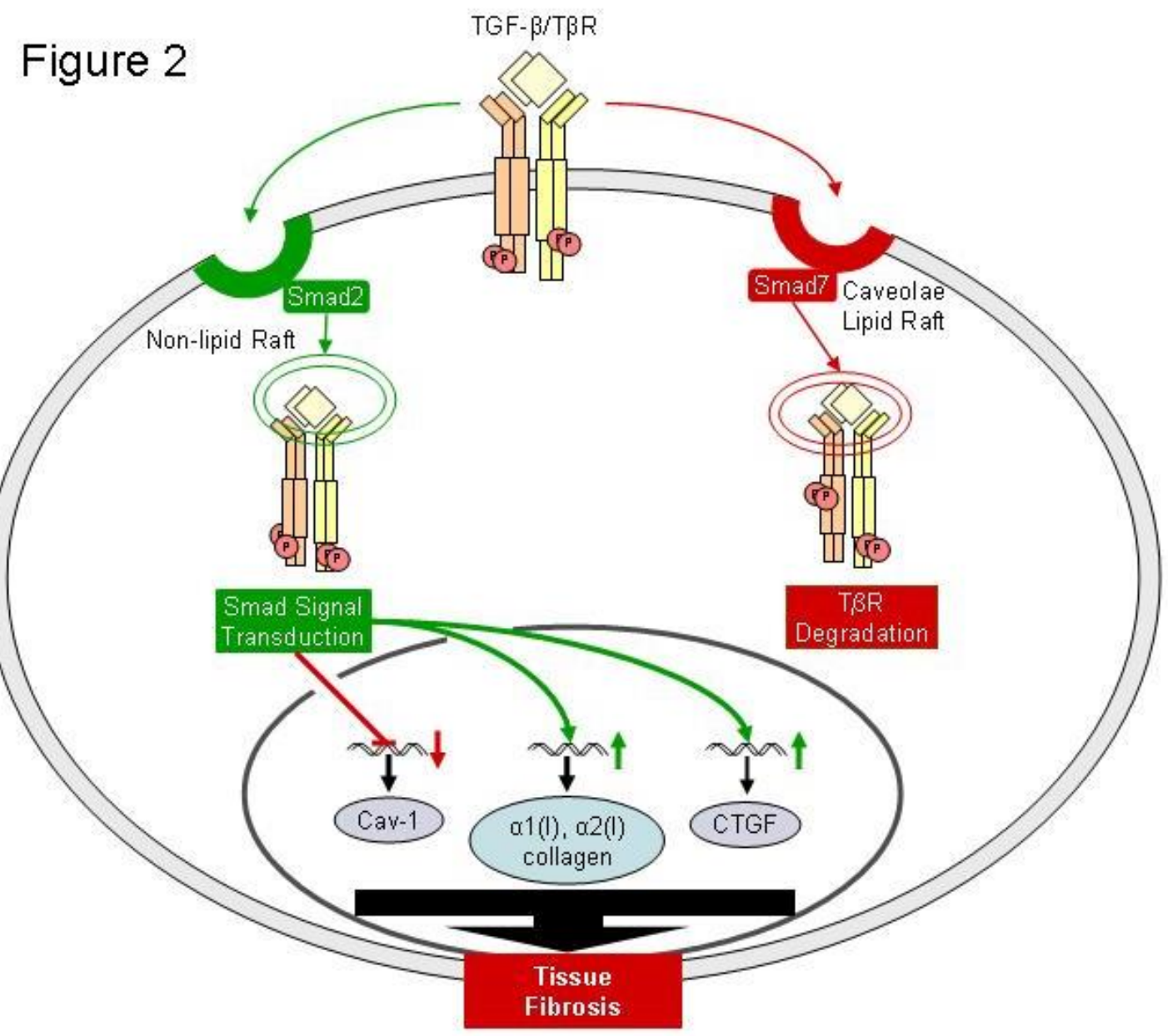

